\section{Relationships Between the Dimensions of Resilience and Burnout in Primary School Teachers}

\author{
M. Inmaculada Vicente de Vera Garcíaa, ${ }^{a}$, M. Inés Gabari Gambarte ${ }^{b}$
}

\begin{tabular}{ll}
\hline Received: & 4 July 2019 \\
Revised: & 19 November 2019 \\
Accepted: $\quad 23$ December 2019 \\
ISSN: 1307-9298 \\
Copyright @ IEJEE \\
www.iejee.com
\end{tabular}

DOI: 10.26822/iejee.2019257666

\title{
Abstract
}

Education professionals are very prone to burnout. Faced with this psychosocial risk, resilience is advocated as a human condition to remake itself in the face of difficulties. The objective of the study was to analyze the relationships between perceptions of burnout and resilience in a sample of 334 teachers from 35 public Primary School Education centers. The accepting sample was composed of 334 teachers (26.34\% of the invited sample). It was a cross-sectional, descriptive and correlational study, which responded to a simple random sampling of 1268 teachers in the $2017 / 2018$ academic year, through voluntary and anonymous participation. The instruments used were the Spanish versions of the Maslach Burnout Inventory-General Survey (MBI-GS) and Connor-Davidson Resilience Scale (CD-RISC). Positive relationships were found between emotional fatigue/exhaustion and depersonalization/cynicism and low levels of resilience, as well as between personal fulfillment/effectiveness and high levels of personal competence, confidence in one's intuition and positive acceptance of change, dimensions typical of the resilient response. The importance of promoting resilient coping strategies such as positivism, tolerance to frustration, locus of internal control and self-efficacy, which act as dimensions of protection against exhaustion, negative dimension of burnout, emerges.

Keywords: Burnout, Depersonalization, Emotional Tiredness, Resilience, Effectiveness, Positivism, Control Locus, Coping Strategies

\section{Introduction}

Education professionals often show loss of emotional resources, mainly caused by the physical, mental, and relational demands of teaching work. The excessive number of students in the classrooms, the excess of tasks to be performed, the temporary pressures and work overload, the lack of support teachers, the inadequacy of schedules, the excessive bureaucracy and the paperwork that derives from it, etc., are related to the emotional fatigue of this group (Longas, Chamarro, Riera, \& Cladellas, 2012; Llull, Cerdà, \& Brage, 2015; Rodríguez, Sola, \& Fernández, 2017; Carlotto \& Câmara, 2017). Additionally, the incidence of other external factors of the work environment, derived from the general and specific characteristics of the personality, family circumstances or the private and social life of the teacher, interact with personal resources and can lead to a decrease in their activity labor, mental and physical, giving rise to disorders such as burnout (Justo 2010; López \& Extremera, 2017; Burgos, Paris, Salcedo, \& Arriagada, 2018).

Maslach (2009) explains the dimensions of burnout with a three-dimensional model, which has the presence of three related but empirically distinct components. Galbán (2018) describes the process of the appearance of Burnout Syndrome: it begins with an imbalance between organizational demands and personal resources caused by emotional exhaustion in the worker; subsequently depersonalization or coping is experienced leading the worker to disappointment and exhaustion; It ends with the low personal accomplishment at work as a result of the inefficiency in facing the different labor stressors.

However, despite the fact that organizational events can be stressful by themselves, some subjects are more vulnerable than others to develop the syndrome (Albar et al., 2004; González, Torres, \& Carreres, 2017; Martos et al., 2018). This depends, in part, on the cognitive strategies used to solve problems, the type of professional exercise and the develop- ment of resistance or protection dimensions that are linked to individual variables, such as personality type and attributes or features of it (Aldas, 2017; Vargas, Niño, \& Acosta, 2017).

There are individual traits such as resilience, self-efficacy, resistance to frustration, locus of control, expectations, etc., that exert a great influence on the evaluation that people make of stressful situations based on the cognitive traits of the personality that, in turn, they condition the type of coping to respond to this stressful situation (Morales, 2017; Noreña, 2018).

Among the resources that prevent the development of burnout, resilience stands out, understood as a strength that human beings develop in the face of adversity, can resist stressful events, get rid of it, and even get stronger from experience (Bonanno, 2004). In the educational field, resilience refers to the potential that each person has (teachers/students ...). The authors who explore resilience point out that some of the characteristics of resilient people are related to cognitive flexibility, creative ability, the ability to solve interpersonal problems, the good level of self-concept and the bonds of attachment that have been forged in the childhood (Saavedra \& Villalta, 2008; Ornelas, 2016).

Numerous studies corroborate that resilience reduces vulnerability to burnout (Stratta et al., 2013; Efilti, 2019), being the ability to cope with stressors one of the keys to resilience. So, the use of constructive coping strategies focused on the problem (such as the search for instrumental social support, positive reinterpretation and acceptance) prevents the development of the syndrome (Medrano, 2017). While the use of passive coping strategies focused on emotion (relief, denial and search for emotional social support) facilitates its appearance (Félix, García, \& Mercado, 2018). Burnout appears when coping strategies are more focused on emotion and avoidance. Thus, resilient people maintain control over their work while remaining stable even in the presence of con- 
flicts, staying involved in the task, seeing obstacles as a challenge to overcome through greater effort, without developing burnout (Cruz \& Puentes, 2017; Serrano, 2018; Vicente de Vera \& Gabari, 2019).

Additionally, some research suggests that positive emotions undo the physiological effects caused by negative emotions. They underline the weight that positive emotions such as optimism, assertiveness and self-esteem, among other aspects, have in the construction of the resilient process (McKergow, 2009; Knowlden, Hackman, \& Sharma, 2016; Díaz \& Barra, 2017). It has been found that an optimistic attitude towards challenging situations is related to confidence and persistence in behavior, even if things get difficult (Oriol, Mendoza, Covarrubias, \& Molina, 2017). On the contrary, a pessimistic attitude makes people manifest doubtful and hesitant (Pulido \& Herrera, 2018). Therefore, giving a positive meaning to life events and having a coping style focused on the problem, helps generate positive emotions when adverse situations are experienced (Dawson \& Pooley, 2013; Martínez \& Ruch, 2017; Alarcón, 2018).

Within the positive personality, another variable that bears some similarity with the concept of resilience, is the strength of character or also called resistant personality. People with this type of personality suffer less work stress and tend to wear less professionally (González, Pelegrín, \& Carballo, 2017). All this leads to that, if a stressful event occurs, the individual has more strategies to cushion it and not see it only in the negative sense, but as a challenge (Vargas et al., 2017; Carrara, 2018).

Also, recent studies assert that resilience improves or maintains, among other factors, professional effectiveness (Tejedor \& Mangas, 2016). On the one hand, because self-effective people do not usually perceive environmental demands as stressful and, on the other, because they try harder (Vélez, López, \& González, 2017). In fact, numerous works argue that burnout occurs as a result of successive crises of effectiveness (Vallejo, 2017; Dios, Calmaestra, \& Rodríguez, 2018). These beliefs have shown their predictive potential in the development of the syndrome. The aforementioned authors explain that an involved subject, with high levels of control and prepared to face challenges, that uses the appropriate coping strategies, performs his work more effectively without giving up the demanding tasks. Therefore, the lack of self-confidence in doing the job well increases the probability of suffering burnout (Lozano \& Reyes, 2017; Peña, Raso, \& Ferrero, 2018). These beliefs have shown their predictive potential in the development of the syndrome.

Another of the personal variables that the scientific literature associates with the development of the syndrome is the control locus (Esteras, Sandín, \& Chorot, 2016). People with internal locus of control have the belief that vital events and their consequences are controlled by their own decisions and actions. On the other hand, subjects with an external control locus are convinced that these events are controlled by external forces, other people, luck or destiny (Vargas, Briñez, Segura, \& Nieto, 2016). These beliefs are relatively stable and have important implications for performance and well-being at work. That is, people with internal locus of control, when they perceive that they have dominion over situations, have more favorable expectations of coping and face the problems by carrying out actions that counteract the effects of adverse conditions (Torres \& Bonilla, 2017). His experience, therefore, is less threatening to stressors than that of people with locus of external control, more prone to homelessness, vulnerability and job dissatisfaction (Islas, Gutiérrez, Castellanos, \& Méndez, 2017).

Given the shortage of studies in our study environment at the primary levels of education, in contrast to the numerous literature on this subject in other contexts such as Latin Amer- ica or Portugal, the work that we present below has as main objective to establish relationships between the dimensions of burnout and the resilience perceived in a sample of Primary Education teachers. As a secondary objective, we consider checking the levels of perceived effectiveness in said group and its influence against burnout. So, given the individual differences in the implementation of coping strategies under threatening or stressful conditions, it is plausible to think that resilience, as well as perceived self-efficacy, could be considered as outstanding modulators of teacher welfare.

\section{Method}

Design

A transversal design is chosen, within a descriptive and correlational model. The independent variable is belonging to a primary school teaching group. Dependent variables, perceived burnout and resilience levels, understood as:

\section{Independent Variable:}

Teachers of public Primary School: professionals who provide training between 6 and 12 years, in centers whose main entity is the administration, so that access is by opposition and their status is that of civil servant or aspiring to be.

\section{Dependent Variables}

1. Burnout: syndrome of physical and emotional exhaustion, which implies the development of negative attitudes towards work, poor self-concept and loss of interest in the activities carried out. Three subvariables:

a. Exhaustion or emotional fatigue: component of individual stress, presence of feelings of weakness and exhaustion in the face of work demands, loss of vital energy and increasing disproportion between the work performed and the fatigue experienced.

b. Cynicism or depersonalization: interpersonal context component, negative, insensitive or excessively apathetic response to various aspects of work, minimization of quality and level of performance.

c. Efficacy or personal fulfillment: self-assessment component, is presented in a reduced way, diminished sense of self-efficacy and achievements at work, aggravated by lack of resources and lack of social support and opportunities to develop professionally. the workers come to have a negative consideration of themselves and others.

2. Resilience or positive adaptation to circumstances of significant adversity: an essential component for good work performance and a basic element for the protection of workers' welfare. Five subvariables or dimensions: personal competence, self-demand and tenacity; confidence in one's intuition and tolerance of adversity; positive acceptance of change and secure relationships; control; spiritual influences.

\section{Participants}

The initial contact for the field study is carried out through an interview with the Management Teams of the selected Primary Education Centers, belonging to the public education network during the 2017/18 academic year, who value the interest of the proposal and they contribute to the dissemination of the Questionnaire among the Cloisters, agreeing: 
1. Sampling criteria: voluntary and anonymous participation of teachers, without identification of the educational center.

2. Online mode of data collection with a single shipment.

3. Active link for one month from the individual reception of the email, as latency time to issue the response.

The invited sample was composed of the population of teachers $(N=1268)$ of Primary School Education. The 14 surveys were excluded because they contain errors. The accepting sample consisted of 334 teachers (26.34\%), with the distribution set out below.

Table 1. Sociodemographic distribution of the accepting sample

\begin{tabular}{lrrrr}
\hline Variables & Man & Woman & Total & Percentage \\
\hline Between 22 and 35 years & 12 & 30 & 42 & 12.57 \\
\hline Between 36 and 45 years & 44 & 64 & 108 & 32.34 \\
\hline Between 46 and 55 years & 62 & 68 & 130 & 38.92 \\
\hline Between 56 and 65 years & 28 & 26 & 54 & 16.17 \\
\hline Less than three years from & 8 & 4 & 12 & 3.59 \\
\hline Three to five years from & 12 & 10 & 22 & 6.59 \\
\hline Five to fifteen years between & 26 & 70 & 96 & 28.74 \\
\hline Fifteen and twenty years & 28 & 26 & 54 & 16.17 \\
\hline More thant wenty years & 78 & 72 & 150 & 44.91 \\
\hline Official & 104 & 132 & 236 & 70.66 \\
\hline Hired & 16 & 20 & 36 & 10.78 \\
\hline Interim & 24 & 32 & 56 & 16.77 \\
\hline Substitute & 2 & 4 & 6 & 1.79 \\
\hline Married or living as a couple & 108 & 138 & 246 & 73.65 \\
\hline Single & 22 & 20 & 42 & 12.57 \\
\hline Others & 4 & 10 & 14 & 4.20 \\
\hline (Empty) & 12 & 20 & 32 & 9.58 \\
\hline No son & 44 & 68 & 112 & 33.53 \\
\hline A son & 30 & 44 & 74 & 22.15 \\
\hline Two children & 56 & 64 & 120 & 35.93 \\
\hline Three children & 14 & 10 & 24 & 7.19 \\
\hline More than three children & 2 & 2 & 4 & 1.20 \\
\hline
\end{tabular}

The distribution of the accepting sample was: 188 women (56.29\%) and 146 men (43.71\%). The highest percentage accumulated was between 46 and 55 years (38.92\%). Teaching exercise experience of more than twenty years (44.91\%). A high percentage $(70.66 \%)$ were civil servants. Also, $73.65 \%$ of teachers were married or living as a couple. As for the offspring, he highlighted the participation of teachers with children. $66.47 \%$ of the teaching staff had a child.

\section{Instruments}

Prior agreement with the Directors of the schools, the information collection instrument used was a single online questionnaire of 46 items with a Likert response with five levels of response, with Cronbach's a reliability of .815 , which allowed us to state that The collected data responded to the intended valuations, combining:

1. The MBI-GS General Services Burnout Inventory (Shaufeli et al., 1996) in the Spanish adaptation of Salanova, Schaufeli, Llorens, Peiró and Grau (2000). The 15 items of the questionnaire were distributed on three scales: Exhaustion, Cynicism and Efficiency. High scores in Exhaustion and Cynicism and low Efficiency scores mean "more burned by work. "In the original version of the MBI-GS, its authors find Cronbach's alpha coefficients ranging from .84 to .90 for Exhaustion, from .74 to .84 for Cynicism, and from, .70 to .78 for Professional Efficacy. In its adaptation to Spanish, the reliability values of the scales according to Cronbach's alpha are .83 for exhaustion .73 for cynicism and .81 for professional effectiveness.

2. The Connor-Davidson Resilience Scale Inventory (CD-RISC) prepared by Connor and Davidson (2003) based on previous work by Kobasa (1979), Rutter (1985) and Lyons (1991). The CD-RISC consists of a total of 25 items distributed in five dimensions that we have named:

- CAT: Personal competence, Self-demand and Tenacity (8 items),

- CTF: Confidence in your own intuition, Tolerance to negative effects and Strength against stress (7 items),

- ARS: Positive acceptance of change and Secure Relationships (5 items),

- CON: Control (3 items),

- IES: Spiritual Influences (2 items).

The scale is classified according to how the subject has felt during the last month. The total score ranges from 0 to 100 and the highest scores reflect greater resilience. The original version has good properties, with a Cronbach's alpha of .89 (general population) and a test-retest reliability of .87 .

Likewise, 4 questions collected information on sociodemographic variables: sex, age range, marital status and number of children, and 2 other questions, on socio-labor variables of the teacher's job: seniority, stability (hired/am official/a, interim or substitute). It was decided not to request the identification of the workplace to avoid a decrease in the level of response, traditionally low on these issues.

\section{Process}

The management teams of the educational centers were contacted by telephone requesting their collaboration to disseminate the questionnaire among teachers via email. A unique questionnaire was designed, and all invited teachers were sent along with the cover letter ensuring anonymity, as well as explaining the objective that was intended to be obtained from data collection. A response receipt period of one month was established. A previous analysis was performed to rule out incomplete or erroneous questionnaires. Teachers participated voluntarily. All terms of the ethical guidelines of the Declaration of Helsinki (AMM, 2000) were respected at all times.

\section{Analysis of Data}

Descriptive statistics were made to obtain the sociodemographic data of the sample and the different variables studied. Then Spearman correlations (values of $p>.20$ ) were made between the three dimensions of burnout (exhaustion, cynicism and efficacy) and the five dimensions of resilience (personal competence, self-demand and tenacity; confidence in one's own intuition and tolerance to adversity; positive acceptance of change and secure relationships; control; spiritual influences), which were processed and analyzed using v22.0 of the IBM SPSS statistical package. 
Significance was set at $p<.01$ and a 99\% confidence level was taken into account for all operations.

\section{Results}

The highest score of the components of the burnout scale was obtained in Personal/Professional Efficacy with a mean of 5.56 $(s d=.83)$, followed by Cynicism with a mean of $3.41(s d=.94)$ and for Emotional Exhaustion with a mean of 3.11 ( $s d=1.25$ ).

Overall, low burnout rates (percentile $<25$ ) were found in the group of participating subjects. Four subjects who indicated burnout were identified (2.40\% of the sample), diagnosed with high exhaustion and cynicism and low efficacy. There were also 14 cases ( $7.18 \%$ of the sample) in which high depletion and cynicism were found with normal efficacy that led us to suspect that there could be more cases (see Table 2).

Table 2. Evaluation of burnout in Primary School teachers (Spain) 2017/18 academic year

\begin{tabular}{lccc}
\hline Burnout cases & $n$ & Percentage & Burnout index \\
\hline $\begin{array}{l}\text { Burnout } \\
\text { syndrome }\end{array}$ & 4 & 2.40 & high \\
\hline $\begin{array}{l}\text { No burnout } \\
\text { effectively <4 }\end{array}$ & 12 & 7.18 & under \\
\hline $\begin{array}{l}\text { No burnout with } \\
\text { exhaustion }>5\end{array}$ & 32 & 19.16 & midle \\
\hline $\begin{array}{l}\text { No burnout } \\
\text { with cynicism }>5\end{array}$ & 18 & 10.78 & midle \\
\hline $\begin{array}{l}\text { No burnout with exhaustion> 5 } \\
\text { and cynicism>5 }\end{array}$ & 14 & 8.38 & midle \\
\hline
\end{tabular}

Regarding the highest means of the components of the resilience scale, they were obtained in the CTF Dimension: Confidence in one's intuition, tolerance for negative effects and strength against stress, with an average of $3.84(s d=.33)$; then the IES Dimension: Spiritual influences, with an average of $2.91(s d=.65)$; The CAT Dimension followed: Personal competence, Self-demand and Tenacity, with an average of 2.8 ( $s d=$ 1.35); Subsequently, the ARS Dimension: Positive acceptance of change and safe relations, with an average of $2.45(s d=1.35)$ and, finally, the CON: Control Dimension, with an average of $2.37(s d=.66)$.

The score of the CD-RISC items was classified as low resilience (first quartile), moderate resilience (second and third quartile) and high resilience (fourth quartile). Given that certain mental problems such as depression and a high perception of stress are associated with less resilience (Connor \& Davidson, 2003) and high levels of resilience are associated with better mental health conditions (Baek, Lee, Joo, Lee, \& Choi, 2010). A total of 44 participants (26.34\%) were positioned in the second and third quartiles. So, the participating teachers were in the medium category of resilience index. Table 3 shows the results of the sample in relation to the various Resilience Dimensions.
Table 3. Resilience assessment in Primary Education teachers (Spain) 2017/18 academic year

\begin{tabular}{lc}
\hline Resilience factors & $\begin{array}{r}\text { Results in each } \\
\text { factor }\end{array}$ \\
\hline $\begin{array}{l}\text { Factor I: personal competence, self-demand and } \\
\text { tenacity }\end{array}$ & $182(54.49 \%)$ \\
\hline $\begin{array}{l}\text { Factor II: confidence in one's own intuition, toler- } \\
\text { ance to negative effects and strength against stress }\end{array}$ & $176(52.69 \%)$ \\
\hline $\begin{array}{l}\text { Factor III: positive acceptance of change and safe } \\
\text { relationships }\end{array}$ & $180(53.89 \%)$ \\
\hline Factor IV: control & $168(50.30 \%)$ \\
\hline Factor V: spiritual influences & $176(52.69 \%)$ \\
\hline
\end{tabular}

The correlation between burnout and resilience levels collected in this study is shown in Table 4.

The data reported in this study reflected the belonging of the sample to an experienced group, highlighting the low participation of the novel teaching staff and with an eventual contract against the official teaching staff that was more collaborative. Likewise, he highlighted the majority participation by women, as well as married teachers and children. Some authors, such as Albar et al. (2004) argue that having children works as a dimension of protection against the syndrome. These authors affirm that this is related to the emotional support received from the family.

The response rate found is an attitude that reflects fear or lack of interest to evidence issues related to burnout in this group and, in turn, may be the reason why it is evidenced by the number of confirmed burnout cases. Authors such as Longas et al. (2012) obtained similar results to those found in this study in an investigation with teachers in Catalonia.

Regarding the levels of resilience, it seems that it tended to develop more in women than in men, an aspect that may be at the base of their coping with adversities in the workplace, inherent in teaching work in the primary stage. In this context, Stratta et al. (2013) compared levels of resilience, finding significant differences in the sources of resilience between men and women, being higher in women, as was the case in this study. Serrano (2018) in an investigation with triathletes, reported that women turn out to be more resistant than men, although the author explains that these differences are not statistically significant.

Likewise, it was the married or living couple professors who scored the highest in resilience compared to the single. Although authors like Justo (2010), confirm that the fact that family problems occur that are distorting the normal functioning of the dynamics of the home, predisposes the person to suffer burnout.

With respect to the dimensions of burnout, the Emotional Exhaustion dimension directly and positively correlated with

Table 4. Correlation between Burnout Dimensions with Resilience dimensions.

\begin{tabular}{lcccccc}
\hline Dimensions & Exhaustion & Cynism & Effectiveness & CAT & CTF & ARS \\
\hline Exhaustion & 1 & $.58^{* *}$ & $-.24^{* *}$ & $.37^{* *}$ & $.20^{* *}$ & $.33^{* *}$ \\
\hline Cynism & $.58^{* *}$ & 1 & $-.21^{* *}$ & $.30^{* *}$ & .06 & $.29^{* *}$ \\
\hline Effectiveness & $-.24^{* *}$ & $-.21^{* *}$ & 1 & $-.18^{*}$ & $.31^{* *}$ & $-.34^{* *}$ \\
\hline CAT & $.37^{* *}$ & $.30^{* *}$ & $-.18^{*}$ & 1 & $.32^{* *}$ &. $.41^{* *}$ \\
\hline CTF & $-.20^{* *}$ & -.06 & $.31^{* *}$ & $.32^{* *}$ & 1 &. $.31^{* *}$ \\
\hline ARS & $-.33^{* *}$ & $-.29^{* *}$ & $.34^{* *}$ & $.56^{* *}$ & $.19^{*}$ & .08 \\
\hline CON & $.61^{* *}$ & $.47^{* *}$ & $-.41^{* *}$ & $.43^{* *}$ & $-.41^{* *}$ & $.26^{* *}$ \\
\hline IES & $-.58^{* *}$ & $-.48^{* *}$ & $.31^{* *}$ & $.50^{* *}$ & $.26^{* *}$ & .08 \\
\hline
\end{tabular}

**The correlation is significant at level .01 (bilateral). ${ }^{*}$ The correlation is significant at level .05 (bilateral). 
Cynicism $(r=.58, p<.01)$ and with some statements pertaining to the Dimensions of the Resilience scale that contained negative aspects of work $(r=.37, p<.01 ; r=.20, p<.01 ; r=.33$, $p<.01 ; r=.61, p<.01$ and $r=.58, p<.01)$. In contrast, the correlation was negative with the Effectiveness dimension ( $r=$-. $24, p<.01)$. In this order of things, the loss of emotional resources caused by the physical, mental, emotional and relational demands of the teaching work (the excessive number of students in the classrooms, the excess of tasks to be performed, the temporary pressures and the overload At work, the lack of support teachers, the inadequacy of schedules, the excessive bureaucracy and the paperwork that derives from it, etc.,) in interaction with individual resources, can negatively impact their health and decrease the teacher feelings of self-efficacy The results obtained in this dimension, confirm the studies of authors such as López and Extremera (2017), Rodríguez et al. (2017) and Galbán (2018) who state that when there are high demands and poor resources at work, this makes it difficult to achieve objectives, feelings of self-efficacy diminish in the teacher and, over time, give rise to the syndrome of burning by work or burnout; that is, emotional exhaustion, cynicism and personal/professional inefficiency.

The Cynicism dimension obtained a direct and positive correlation with the emotional exhaustion dimension $(r=.58$, $p<.01$ ) and with statements belonging to the dimensions of the resilience scale that contained negative aspects of the work $(r=.30, p<.01 ; r=.06, p<.05 ; r=.29, p<.01 ; r=.47, p<$ $.01 ; r=.48, p<.01)$. On the contrary, it correlated negatively with some judgments of the personal / professional effectiveness dimension $(r=-.21, p<.01)$. Coinciding with these assessments, Llull et al. (2015) underline that negative interactions with students (frictions, conflicts and disputes) are related, on the one hand, positively with emotional exhaustion and depersonalization and, on the other, negatively with low personal achievement. The same opinion is expressed by Maslach (2009), Carlotto and Câmara (2017), Burgos et al. (2018) and Vicente de Vera and Gabari (2019), who report that workers with greater emotional fatigue are those who feel more cynicism and less personal fulfillment.

On the other hand, the Personal / Professional Effectiveness dimension was negatively correlated with Emotional Exhaustion $(r=-.24, p<.01)$, with Cynicism $(r=-.21, p<.01)$ and with some issues of Resilience that referred to some negative aspects of teaching work $(r=-.18, p<.05 ; r=-.34, p<.01 r=$ $-.41, p<.01 ; r=-.31, p<.01)$. Although it obtained a direct correlation with the positive aspects of the work contained in the Resilience scale $(r=.31, p<.01)$. Thus, the positive features of the work, such as: realistic employment objectives, participation in decision-making, autonomy, organizational support, availability of resources, etc., increase the perceived effectiveness of the teacher, which allows him to control the demands and It enables you to believe in your own abilities. Tejedor and Mangas (2016) and Cruz and Puentes (2017) explain that, as self-efficacy decreases, feelings of emotional exhaustion and cynicism that cause burnout increase. Other authors, such as Peña et al. (2018) report that the subject's perception of feeling effective with the tasks he performs plays a relevant role in the development of the syndrome. They affirm that a subject involved with high levels of control and prepared to face challenges, using appropriate coping strategies, performs his or her work more effectively without surrendering to demanding tasks.

On the other hand, the Personal/Professional Effectiveness dimension was negatively correlated with Emotional Exhaustion $(r=-.24, p<.01)$, with Cynicism $(r=-.21, p<.01)$ and with some issues of Resilience that referred to some negative aspects of teaching work $(r=-.18, p<.05 ; r=-.34, p<.01$; $r=-.41, p<.01 ; r=-.31, p<.01)$. Although it obtained a direct correlation with the positive aspects of the work contained in the Resilience scale $(r=.31, p<.01)$. Thus, the positive features of the work, such as: realistic employment objectives, participation in decision-making, autonomy, organizational support, availability of resources, etc., increase the perceived effectiveness of the teacher, which allows him to control the demands and It enables you to believe in your own abilities. Tejedor and Mangas (2016) and Cruz and Puentes (2017) explain that, as self-efficacy decreases, feelings of emotional exhaustion and cynicism that cause burnout increase. Other authors, such as Peña et al. (2018) report that the subject's perception of feeling effective with the tasks he performs plays a relevant role in the development of the syndrome. They affirm that a subject involved with high levels of control and prepared to face challenges, using appropriate coping strategies, performs his or her work more effectively without surrendering to demanding tasks.

In sum, efficacy beliefs decrease the likelihood of a teacher experiencing stress under certain conditions (Lozano \& Reyes, 2017; Vélez et al., 2017). On the contrary, people who judge themselves as ineffective value their own deficiencies more, as well as potential difficulties, so they are more likely to experience stress (Vallejo, 2017; Dios et al., 2018). So, the lack of self-confidence in performing the tasks well increases the probability of suffering burnout.

Regarding the scores reported in the Dimensions of the resilience scale, the results showed that the CAT dimension (personal confidence, self-demand and tenacity) correlated positively with emotional exhaustion $(r=.37, p<.01)$, Cynicism $(r=.30, p<.01)$ and with the negative aspects contained in the CTF dimension, $(r=.32, p<.01)$, ARS dimension, $(r=.56$, $p<.01)$, CON dimension, $(r=.43, p<.01)$ and IES dimension $(r=$ $.50, p<.01)$ of the Resilience scale. Instead, it correlated negatively with Efficacy $(r=-.18, p<.05)$. In line with these results, Aldás (2017) also found significant correlations in a positive sense between emotional fatigue and negative avoidance and auto-focalization strategies. On the other hand, Felix et al. (2018) point out that inappropriate strategies, of the escapist type, increase the probability of suffering burnout, as indicated by the correlations of Dimension I that we have just explained. So, when the individual uses coping strategies that are not right to deal with a certain situation, the possibility of suffering burnout increases.

The CTF dimension, confidence in one's intuition, tolerance for negative effects and strength against stress, presented a significant association with the Effectiveness dimension ( $r=$ $.31, p<.01)$, with the ARS dimension $(r=.19, p<.05)$, dimension CON $(r=.08, p<.01)$ and dimension IES $(r=.26, p<.01)$, of the Resilience scale. On the other hand, the association was negative with emotional exhaustion $(r=-.20, p<.01)$ and Cynicism $(r=-.06, p<.05)$. Referring to the correlations of this Dimension, Ornelas (2016), González et al. (2017) and Alarcón (2018) emphasize that some people are more resistant to stressors, which allows them to implement coping strategies to overcome the demands that generate stress and allows them to achieve an effective response to restore the balance of situation. They add that this enables them to implement coping strategies to overcome the demands and allows them to achieve an effective response to restore the balance of the situation. On the other hand, Medrano (2017), Noreña (2018) and Martos et al. (2018) confirm that the use of stress coping strategies focused on the problem, such as those found in this component, prevents the development of the syndrome.

The ARS dimension, positive acceptance of the change, obtained a significant association with Efficacy $(r=.34, p<.01)$, with the CAT dimension $(r=.56, p<.01)$, the CTF dimension, $(r=.19, p<.05)$ and IES dimension $(r=.54, p<.01)$. The association was negative with the CON dimension $(r=-.41, p<.01)$ of the Resilience. In relation to these data, Dawson and Pooley 
(2013), Knowlden et al. (2016), Martínez and Ruch (2017) and Oriol et al. (2017), among others, express that the experience of positive emotions is nothing more than the reflection of a resilient way of dealing with adverse situations. Previous studies by authors such as Gómez and Cavaco (2016), Díaz and Barra (2017) and Alarcón (2018) show that positive emotions mainly cause changes in cognitive activity and subsequently changes in the behavioral sphere. This favors the construction of personal resources (physical, psychological and social) to face difficult or problematic situations that foster an adaptive or resilient coping style (Bonnano, 2004; Saavedra \& Villalta 2008; Morales, 2017; Efilti, 2019). Additionally, Pulido and Herrera (2018) report that optimism exerts a differential influence in the assessment and coping with difficulties, in the development in the social and academic world and in the psychic and physical well-being of people and, they point out, that optimism and pessimism correlate significantly with self-efficacy and professional wear in a diverse way.

The CON dimension maintains a positive correlation with Exhaustion $(r=.61, p<.01)$, Cynicism $(r=.47, p<.01)$ and with the negative aspects contained in the CAT dimension $(r=.43, p<$ $.01)$. However, the correlation is negative with the Efficacy $(r=-.41, p<.01)$, with the CTF dimension $(r=-.41, p<.01)$ and with the IES dimension, $(r=-.59, p<.01)$ of the Resilience. As has been described, this dimension is related to a personality trait called a locus of control that refers to the control that the subject is attributed to his actions. In this sense, Esteras et al. (2016) report that people with internal control locus perceive that they have dominion over situations and have more favorable coping expectations. As a consequence, they face problems by taking actions that counteract the effects of adverse conditions. His experience is less threatening to stressors than that of people with locus of external control more prone to homelessness, vulnerability and job dissatisfaction. So, teachers with internal control locus, that is, who believe that the events that occur in their environment are a consequence of their behaviors and, therefore, controllable, evaluate teaching as less stressful (Torres \& Bonilla, 2017). On the contrary, teachers who show locus of external control are more likely to suffer burnout. Regarding these statements, Vargas et al. (2016), among other authors, report that this affects greater emotional exhaustion and cynicism and less personal/professional effectiveness. That is, in the face of ambiguous, difficult or novel situations in which the subject believes he has little or no chance of controlling, there is a greater chance of the syndrome appearing (Islas et al., 2017).

Finally, the IES dimension, spiritual influences, reflects high scores in teachers with resilient personality. The correlation was positive with the Efficacy dimension $(r=.31, p<.01)$, the CAT dimension ( $r=.05, p<.01)$, the CTF dimension, $(r=.26$, $p<.01)$ and the ARS dimension $(r=.54, p<.01)$. On the contrary, the correlation is negative with Emotional exhaustion ( $r=-.58$, $p<.01)$, Cynicism $(r=-.48, p<.01)$ and the CON dimension $(r=$ $-.59, p<.01)$ of the Resilience scale. In relation to these assessments, González et al. (2017) and Carrara (2018), report that people with resilient personality are more effective in coping with stress and tend to wear less professionally, compared to those without this personality pattern.

\section{Conclusions}

The results found in this study allow establishing levels of relationship between burnout and resilience expressed. In the presence of situations of labor adversity, the most resilient teachers do not get burned, but achieve greater skills and competencies of work commitment, while having the ability to use their energy and personal involvement to overcome difficulties, adapt appropriately and experience positive emotions. On the other hand, less resilient teachers are predisposed to negative emotions, to overestimate risk, and to increase their effect with fatigue and indifference at work. It is concluded that resilience reduces vulnerability to burnout.
Likewise, some variables (eg, positivism, constructive coping strategies, high resistance to frustration, self-efficacy, etc.) with which the subject faces labor demands, act as protective dimensions against burnout. While risk dimensions (eg, emotional coping strategies, poor tolerance to frustration, negative family climate, poor job opportunities, etc.) are an important predictor in the development of the syndrome.

On the contrary, an effective response to contextual demands, such as that expressed by participating teachers, is directly related to self-efficacy, understood as that internal sensation that the person experiences, which leads him to feel and think that he is competent and enables him to believe in his own abilities. These self-efficacy judgments influence the goals that people set and their affective responses to the levels of achievement achieved. In short, when you have a strong sense of effectiveness, control over the tasks to be performed is enhanced and this control helps to perceive work as a challenger, full of meaning and purpose; to feel satisfaction when doing the tasks, motivation to do a good job. So, the positive levels of self-efficacy found in this study protect the group of participating teachers against burnout.

It is concluded that some personal variables, such as resilience and self-efficacy, protect the teaching staff of this study against burnout syndrome. From these lines, we emphasize that personal resources can be the object of the institutional approach of continuous training in the line of Health Prevention and Promotion in the educational field of Primary Education. Together with them, family cohesion and social support, among others, with which the person faces labor demands, act as protective dimensions against burnout.

The findings in this study regarding burnout syndrome and resilience need in the future the design of adequate research to know in more detail the implications that both constructs have in the work of these professionals. We emphasize the importance of the development of resilience in teacher performance to meet labor demands, as it acts as a buffer for stressors and reduces vulnerability to burnout. We also have an impact on the determining influence that self-efficacy has on the successful performance, motivation and persistence of these professionals.

Despite all of the above, this investigation is not without limitations. One of the limitations of the study points to the interest of deepening the results found transversally with a longitudinal follow-up. In addition, the sample used represents a very specific group, which makes it not possible to generalize the data to teachers of other levels (Secondary) or fields (private schools). The study opens possible lines of research to comparative approaches with other autonomous communities, intercultural or transnational studies, etc. However, the results presented may have practical repercussions in order to facilitate the welfare of Primary schools' teachers.

\section{References}

Alarcón, M. E. B. (2018). Estrés y Burnout Enfermedades En La Vida Actual. Palibrio.

Albar, M. J., Romero, M. E., González, M. D., Carbayo, E., García, A., Gutiérrez, I., \& Algaba, S. (2004). Apoyo social, características sociodemográficas y burnout en enfermeras y auxiliares del hospital. Enfermería Clínica, 14(5), 281 285. doi: 10.1016/S1130 8621(04)73899-1

Aldás, A. C. (2017). Estrategias de afrontamiento y síndrome de burnout en personal de salud (Thesis, Universidad Técnica de Ambato-Facultad de Ciencias de la Salud-Carrera de Psicología Clínica). Recuperado de:http://repo. uta.edu.ec/bitstream/123456789/26500/2/Ana\%20 Carolina\%20Ald\%C3\%A1s\%20Villac\%C3\%ADs\%20pdf. pdf 
Baek, H. S., Lee, K. U., Joo, E. J., Lee, M. Y., \& Choi, K. S. (2010). Reliability and validity of the Korean version of the Connor-Davidson Resilience Scale. Psychiatry investigation, 7(2), 109-115.

Bonanno, G. A. (2004). Loss, trauma, and human resilience: have we underestimated the human capacity to thrive after extremely aversive

Bresó, E., Salanova, M., Schaufeli, W. B., \& Nogareda, C. (2007). NTP No 732. Síndrome de estar quemado por el trabajo Burnout (III): Instrumento de medición. Madrid: Instituto Nacional de Seguridad e Higiene en el Trabajo, Ministerio de Trabajo y Asuntos Sociales.

Burgos, A. L. V., Paris, A. P. D., Salcedo, A. G. S., \& Arriagada, A. A. (2018). Psychological well-being and burnout in primary health care professionals in the region of Los Lagos, Chile. Acta Universitaria, 28(3), 56-64.

Carlotto, M. S., \& Câmara, S. G. (2017). Psychosocial Risks Associated with Burnout Syndrome Among University Professors. Avances en Psicología Latinoamericana, 35(3), 447-457. doi.org/10.12804/revistas.urosario. edu.co/apl/a.4036

Carrara, J. L. (2018). Personalidad resistente y su relación con el egreso voluntario en call centers. Revista de Psicología, 36(1), 239-263. doi.org/10.18800/psico.201801.009

Connor, K.M., \& Davidson, J.R.T. (2003). Development of a new resilience scale: The Connor-Davidson resilience scale (CD-RISC). Depression and Anxiety, 18(1), 76-82. doi.org/10.1002/da.10113

Cruz, D. M., \& Puentes, A. (2017). Relationship between different dimensions of the Burnout syndrome and the coping strategies implemented by security guards at a private corporation from Tunja (Col). Psicogente, 20(38), 268-281.

Dawson, M., \& Pooley, J. A. (2013). Resilience: The Role of Optimism, Perceived Parental Autonomy Support and Perceived Social Support in First Year University Students. Journal of Education and Training Studies, 1(2), 38-49. doi: 10.11114/jets.v1i2.137

Díaz, C., \& Barra, E. (2017). Resiliencia y satisfacción laboral en profesores de colegios municipales y particulares subvencionados de la comuna de Machalí. Estudios pedagógicos (Valdivia), 43(1), 75-86. doi.org/10.4067/ S0718-07052017000100005

Dios, I., Calmaestra, J., \& Rodríguez, A. J. (2018). Validación de la escala de competencias docentes organizacionales y didácticas para educadores. Revista mexicana de investigación educativa, 23(76), 281-302. doi. org/10.11144/Javeriana.upsy15-1.aavm

Efilti, E. (2019). Investigating the Psychological Resilience of Fathers with Mentally Handicapped Children. International Electronic Journal of Elementary Education, 11(4), 353-360.

Esteras, J., Sandín, B., \& Chorot, P. (2016). El síndrome de burnout en los docentes: Los efectos de las variables psicosociales. In Psicología y educación: Presente y futuro (pp. 1177-1185).

Félix, R. O., García, C., \& Mercado, S. M. (2018). El estrés en el entorno laboral. Revisión genérica desde la teoría. CULCYT, (64), 31-42.
Galbán, K. F. (2018). Los riesgos psicosociales en el trabajo: un reto colectivo en el desarrollo laboral cubano. Lex Social: Revista de Derechos Sociales, 8(1), 174-205.

Gómez, M. C. A., \& Cavaco, N. A. A. P. (2016). La resiliencia del docente como Dimensión crucial para superar las adversidades en una sociedad de cambios. Tendencias pedagógicas, 28(1), 167-180.

González, H., Pelegrín, A., \& Carballo, J. (2017). Ira y personalidad resistente en deportistas de raqueta y resistencia. Revista Iberoamericana de Ciencias de la Actividad Física y el Deporte, 6(2), 21-29. doi.org/10.24310/riccafd.2017.v6i2.3776

González, T. M. P., Torres, L. H., \& Carreres, A. L. (2017). Fortalezas y virtudes personales del profesorado y su relación con la eficacia docente. International Journal of Developmental and Educational Psychology (Revista INFAD de Psicología), 7(1), 141-150. doi.org/10.17060/ ijodaep.2014.n1.v7.785

Islas, R. A. C., Gutiérrez, F. J. C., Castellanos, J. L., \& Méndez, K. P. (2017). Síndrome de burnout en médicos docentes de un hospital de $2^{\circ}$ nivel en México. $E d$ ucación Médica, 18(4), 254-261. doi.org/10.1016/j. edumed.2016.09.001

Justo, C. F. (2010). Intervención sobre los niveles de burnout y resiliencia en docentes de educación secundaria a través de un programa de conciencia plena (mindfulness) Revista Complutense de Educación, 21(2), 271 288.

Knowlden, A. P., Hackman, C. L., \& Sharma, M. (2016). Lifestyle and mental health correlates of psychological distress in college students. Health Education Journal, 75(3), 370-382.

Kobasa, S. C. (1979). Stressful life events, personality, and health: an inquiry into hardiness. Journal of personality and social psychology, 37(1), 1-11.

Llull, D. S., Cerdà, M. X. M., \& Brage, L. B. (2015). Malestar social ymalestar docente: una investigación sobre el síndrome de desgaste profesional burnout y su incidencia socioeducativa. Aula: Revista de Pedagogía de la Universidad de Salamanca, 21(1), 245-257. doi:10.14201/aula201521245257

Longas, J., Chamarro, A., Riera, J., \& Cladellas, R. (2012). La incidencia del contexto interno docente en la aparición del Síndrome del Quemado por el trabajo en profesionales de la enseñanza. Revista de Psicología del Trabajo y de las Organizaciones, 28(2), 107-118. doi:10.5093/tr2012a9

López, S. M., \& Extremera, N. (2017). Estado de la cuestión sobre inteligencia emocional y burnout en el profesorado por países, año de publicación, ciclos educativos e instrumentos de evaluación. Profesorado, Revista de Currículum y Formación del Profesorado, 21(3), 371-389.

Lozano, C. R., \& Reyes, M. (2017). Docentes universitarios: Una mirada desde la Autoeficacia general y engagement laboral. Revista Digital de Investigación en Docencia Universitaria, 11(1), 134-148. https://doi. org/10.19083/ridu.11.503

Lyons, J. A. (1991). Strategies for assessing the potential for positive adjustment following trauma. Journal of Traumatic Stress, 4(1), 93-111. 
Martínez, M. L., \& Ruch, W. (2017). Character strengths predict resilience over and above positive affect, self-efficacy, optimism, social support, self-esteem, and life satisfaction. The Journal of Positive Psychology, 12(2), 110-119. doi.org/10.1080/17439760.2016.1163403

Martos, Á., del Carmen Pérez-Fuentes, M., del Mar Molero, M., Gázquez, J. J., del Mar Simón, M., \& Barragán, A. B. (2018). Burnout y engagement en estudiantes de Ciencias de la Salud. European Journal of Investigation in Health, Psychology and Education, 8(1), 23-36. doi. org/10.30552/ejihpe.v8i1.223

Maslach, C. (2009). Comprendiendo el burnout. Ciencia \& Trabajo, 11(32), 37-43.

McKergow, M. (2009). Positivity: Groundbreaking research reveals how to embrace the hidden strengths of positive emotions, overcome negativity and thrive. InterAction, 1(1), 89

Medrano, F. M. (2017). Estilos de afrontamiento del estrés que aplica el profesional de enfermería en el servicio de emergencia del Hospital Nacional Daniel Alcides Carrión mayo-2016. Recuperado de: http://repositorio. upsjb.edu.pe/handle/upsjb/1368

Morales, F. M. (2017). Relaciones entre afrontamiento del estrés cotidiano, autoconcepto, habilidades sociales e inteligencia emocional. European Journal of Education and Psychology, 10(1), 41-48. doi.org/10.1016/j. ejeps.2017.04.001

Mundial, A. M. Declaración de Helsinki de la AMM. Principios éticos para las investigaciones médicas en seres humanos [internet]. Edimburgo, Escocia: 52. a Asamblea General; 2000 oct.[citado 10 dic. 2016].

Noreña, H. (2018). Estrés académico y estrategias de afrontamiento en estudiantes de primer, segundo y tercer semestre de la Facultad de Ingeniería de la Universidad de Antioquia, 2017 (Doctoral dissertation, Psicologia). Recuperado de: http://200.24.17.74:8080/jspui/bitstream/fcsh/1138/1/Nore\%C3\%B1aHenry_2018_Estr\%C3\%A9sAcad\%C3\%A9micoEstrategias\%20.pdf

Oriol, X., Mendoza, M., Covarrubias, C. G., \& Molina, V. M. (2017). Emociones positivas, apoyo a la autonomía y rendimiento de estudiantes universitarios: el papel mediador del compromiso académico y la autoeficacia. Revista de Psicodidáctica, 22(1), 45-53. doi. org/10.1016/S1136-1034(17)30043-6

Ornelas, P. E. (2016). Estrategias de afrontamiento y resiliencia en cuidadores primarios con duelo. Revista Psicología y Salud, 26(2), 177-184.

Peña, J. E., Raso, P. C., \& Ferrero, B. S. (2018). El síndrome de burnout en los docentes. Ediciones. Pirámide.

Pulido, F., \& Herrera, F. (2018). Predictors of Happiness and Emotional Intelligence in Secondary Education. Revista Colombiana de Psicología, 27(1), 71-84. doi. org/10.15446/rcp.v27n1.62705

Rodríguez, A. M., Sola, T., \& Fernández, M. (2017). Impacto de Burnout en el desarrollo profesional del profesorado universitario. Una revisión de la investigación. Revista Electrónica Interuniversitaria de Formación del Profesorado, 20(3), 161-178. doi.org/10.6018/reifop.20.3.275121

Rutter, M. (1985). Resilience in the face of adversity: Protective Dimensións and resistance to psychiatric disorder. The British Journal of Psychiatry, 147(6), 598-611.
Saavedra, E., \& Villalta, M. (2008). Escala de Resiliencia SV-RES para jóvenes y adultos. Santiago: events? American psychologist, 59(1), 20-28. doi: 10.1037/0003-066X.59.1.20

Salanova, M., Schaufeli, W. B., Llorens, S., Peiró, J. M., \& Grau, R. (2000). Desde el burnout al engagement: ¿una nueva perspectiva? Revista de Psicología del Trabajo y las Organizaciones, 16(1), 117-134.

Schaufeli W. B., Leiter M. P., Maslach, C., \& Jackson S. E. (1996). The Maslach Burnout Inventory: General Survey (MBI-GS). In C. Maslach, S., Jackson \& M. Leiter (eds.): Maslach Burnout Inventory Manual, $3^{a}$ ed. (pp. 19-26). Palo Alto, California: Consulting Psychologists Press.

Serrano, J. (2018). Resiliencia, optimismo y burnout en triatletas de un club deportivo de running, trail y triathlon. Recuperado de:http://hdl.handle.net/11201/147817

Stratta, P., Capanna, C., Patriarca, S., de Cataldo, S., Bonanni, R. L., Riccardi, I., \& Rossi, A. (2013). Resilience in adolescence: gender differences two years after the earthquake of L'Aquila. Personality and Individual Differences, 54(3), 327-331. doi:10.1016/j.paid.2012.09.016

Tejedor, E. M., \& Mangas, S. L. (2016). La autoeficacia y la autorregulación como variables moderadoras del estrés laboral en docentes de Educación Primaria. Universitas Psychologica, 15(1), 15-28.

Torres, D., \& Bonilla, L. R. (2017). Burnout académico en estudiantes de psicología. Psicolnnova, 1(1), 1-15.

Vallejo, M. (2017). Una aproximación al síndrome de burnout y las características laborales de emigrantes españoles en países europeos. Revista de Psicología del Trabajo y de las Organizaciones, 33(2), 137-145. doi.org/10.1016/j. rpto.2017.02.001

Vargas, L. D., Niño, C. L., \& Acosta, J. Y. (2017). Estrategias que modulan el síndrome de Burnout en enfermeros (as): una revisión bibliográfica. Revista Ciencia y Cuidado, 14(1), 111-131. doi.org/10.22463/17949831.810

Vélez, A. P., López, J. J., \& González, J. B. (2017). Habilidades emocionales y profesionalización docente para la educación inclusiva en la sociedad en red. Contextos Educativos. Revista de Educación, 20(1), 201-215. doi. org/10.18172/con.3011

Vicente de Vera, M. I., \& Gabari, M. I. (2019). Liderazgo Pedagógico en Educación Secundaria: Aportaciones desde la Evaluación de Burnout-Resiliencia en Docentes. International Journal of Educational Leadership and Management, 7(1), 104-134. doi.org/10.17583/ ijelm.2018.3519

Vicente de Vera, M. I., \& Gabari, M. I. (2019). “Potential of teacher resilience before educational changes". International Journal of Development Research, 9(03), 26712-26718. 